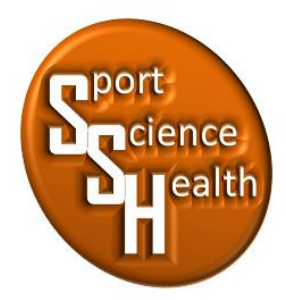

ISSN 2715-3886

\title{
Upaya Meningkatkan Hasil Belajar Keterampilan Passing Atas Bolavoli Dalam Pembelajaran Pendidikan Jasmani Menggunakan Metode Bermain Untuk Siswa SMK
}

\author{
Frisma Dwi Cahyanti ${ }^{1 *}$, Eko Hariyanto ${ }^{2}$ \\ 1,2Jurusan Pendidikan Jasmani, Kesehatan dan Rekreasi, Fakultas IImu Keolahragaan, \\ Universitas Negeri Malang, Jalan Semarang No 5, Malang, Jawa Timur, 65145, Indonesia \\ *Penulis koresponden: frismacahyanti95@gmail.com, 081358545928
}

Artikel diterima: 1 Januari 2021; direvisi: 15 Maret 2021; disetujui: 20 Maret 2021

\begin{abstract}
The research objective was to improve the results of learning passing on volleyball for class XCatering Services 3 SMK Negeri 1 Batu Kota. This study uses quantitative data analysis with classroom action research (CAR), and uses a testinstrument. The research subjects were students of class X Catering Services 3 at SMKN 1 Batu, totaling 35 students. Based on the results of the study, it can be concluded that the initial attitude, attitude attitude, and final attitude on volleyball passing skills showed a significantincrease, which was included in the very good category.
\end{abstract}

Keyword: volleyball, passing over, playing methods

\begin{abstract}
Abstrak:Tujuan penelitian adalah untuk meningkatkan hasil belajar passing atas bolavoli siswa kelas XJasaBoga 3 SMK Negeri 1 Batu Kota. Penelitian ini menggunakan analis is data secara kuantitatif dengan metode penelitian tindakan kelas (PTK), serta menggunakan instrumen berupa tes. Subjek penelitian adalah siswa kelas XJasaBoga 3 SMKN 1 Batu yang berjumlah 35 siswa. Berdas arkan hasil penelitian dapat disimpulkan bahwa sikap awal, sikap perkenaan, dan sikap akhir pada keterampilan passing atas bolavoli menunjukkan adan ya peningkatan yang signifikan yaitu masuk pada pada kategori baik sekali.
\end{abstract}

Kata kunci: bolavoli, passing atas, metode bermain

\section{PENDAHULUAN}

Pendidikan olahraga yang terdapat di sekolah SMK/SMA adalah pendidikan jasmani, olahraga dan kesehatan (PJOK). PJOK merupakan salah satu bagian dari pendidikan secara keseluruhan, yang bertujuan meningkatkan kebugaran jasmani, membangun keterampilan gerak peserta didik, keterampilan berfikir, keterampilan sosial, membangun moral, dan pola hidup sehat dan menjaga lingkungan bersih.

Pendidikan jasmani merupakan suatu media untuk mendorong perkembangan keterampilan motorik, kemampuan fisik, pengetahuan, penalaran, penghayatan nilai (sikap-mental-emosional-spiritual-sosial), dan kebiasaan pola hidup sehat yang menjadi pusat untuk merangsang pertumbuhan serta perkembangan yang seimbang (Anastasiia \& Physical, 2017; Department for Education, 2013; Physical \& Tools, 2014; Willis et al., 2013). Pada hakikatnya, pendidikan jasmani dan kesehatan adalah Pendidikan Jasmani sangat penting bagi 
peserta didik, karena melalui pendidikan jasmani peserta didik dapat berinteraksi dalam melakukan aktivitas jasmani (Oh \& Graber, 2019; Sprake \& Temple, 2016; Tenpaku et al., 2018; Usher et al., 2016). Tercapainya pembelajaran pendidikan jasmani sangat tergantung dengan kemampuan pendidik yang bisa memberi pengetahuan kepada peserta didik, karena apabila pendidik memberikan pengajaran yang mudah dipahami atau bermutu itu akan menghasilkan pembelajaran yang efektif.

Peran pendidik sangat penting sebagai proses pembinaan PJOK yang diajarkan di sekolah, melalui interaksi antara peserta didik dengan lingkungan yang dikelola secara sistematis akan menghasilkan pembentukan manusia seutuhnya. Salah satu bentuk interaksinya dengan melalui aktivitas jasmani. Aktivitas jasmani dapat diartikan sebagai peserta didik untuk meningkatkan keterampilan motorik dan fungsional. Dengan kata lain, pembelajaran PJOK yang dikembangkan harus dapat memacu pada pembentukan, pengembangan dan peningkatan kualitas kemampuan unsur-unsur kognitif, afektif, dan psikomotorik. Pendidikan jasmani juga diartikan sebagai aktifitas fisik, karena salah satu tujuan utama yang menjadi salah satu prioritas dalam penjas adalah penguasaan keterampilan motorik.

Pembelajaran permainan bola besar yang diajarkan salah satunya adalah bolavoli. Permainan bolavoli memiliki 4 teknik dasar yaitu service, passing, smash, dan block. Penguasaan teknik dasar bolavoli harus dilakukan dengan baik, supaya dapat menciptakan suatu permainan bolavoli yang sempurna. Permainan bolavoli merupakan cabang olahraga beregu yang dimainkan oleh enam orang setiap regu. Permainan bolavoli akan berjalan dengan baik apabila setiap pemain dapat menguasai teknik dasar bermain bolavoli (Allard \& Starkes, 2016; Marques Junior, 2018; Reeser et al., 2013; Tilp \& Rindler, 2013; Zhang, 2016). Dalam permainan bolavoli teknik yang paling dasar yang harus dikuasai adalah passing. Teknik melakukan passing terdapat kriteria-kriteria gerakan yang harus diperhatikan. Bolavoli merupakan permainan beregu, tetapi meskipun demikian kemampuan perseorangan yang tinggi, akan memudahkan dalam melakukan suatu kerja sama hingga dapat memberikan hasil akhir yang baik (Ajeesh \& Pradeep, 2013; Beardt et al., 2018; Mergheş et al., 2014; Palao \& sup 2, 2014). Passing atas merupakan teknik dasar bolavoli yang harus diperhatikan, karena teknik dasar passing atas sering kali dilakukan dengan sesuai kemampuan peserta didik, jadi masih banyak yang belum bisa melakukan dengan teknik yang benar.

Berdasarkan hasil observasi awal pelaksanaan kegiatan pembelajaran PJOK yang dilakukan pada tanggal 14 Februari 2018 pada materi passing atas bolavoli pada 35 siswa di kelas X Jasa Boga 3 SMKN 1 Batu ditemukan bahwa $69 \%$ siswa salah dalam melakukan sikap persiapan, $74 \%$ siswa salah dalam melakukan sikap perkenaan, dan 74\% siswa salah dalam melakukan sikap akhir pada teknik passing atas bolavoli.

Dengan adanya penelitian ini diharapakan meningkatkan hasil belajar passing atas bolavoli dalam pendidikan jasmani siswa kelas X Jasa Boga 3 SMK Negeri 1 Batu.

\section{METODE}

Metode yang digunakan dalam penelitian ini metode penelitian tindakan kelas (PTK). PTK merupakan penelitian yang muncul karena dipicu oleh kesadaran diri guru bahwa praktik dalam proses pembelajaran yang dilakukan selama ini di kelas mempunyai masalah yang perlu diselesaikan (Ariffiansyah, 2019; Hendarto et al., 2020; Utami \& Winarno, 2020; Wahyudi et al., 2020). Penelitian tindakan kelas (classroom action research) yang berarti penelitian yang dilakukan pada sebuah kelas untuk mengetahui akibat tindakan yang diterapkan pada suatu subyek penelitian di kelas tersebut (Bryman \& Bell, 2015; Curry-Sumner \& van der Schaaf, 2018; Kumar et al., 2013; Schulz, 2017). Penelitian ini terdapat dua siklus, yang masing-masing siklus terdiri dari tiga pertemuan. Kekurangan waktu pada penelitian ini adalah penelitian dilakukan satu kali dalam satu minggu yang dilaksanakan pada jam mata pelajaran pendidikan jasmani disekolah tersebut. Teknik analisis data menggunakan teknik analisis kualitatif dan kuantitatif. Teknik analisis deskriptif kualitatif diperoleh dari catatan lapangan, hasil observasi dari kegiatan pembelajaran yang berlangsung, dan hasil wawancara dengan guru pendidikan jasmani di kelas X Jasa Boga SMK Negeri 1 Batu. Sedangkan data dari analisis deskriptif kuantitatif berupa presentase. Teknik ini digunakan untuk menganalisis data yang diperoleh dari hasil observasi dengan menggunakan lembar pengamatan. 
Berdasarkan hasil observasi awal Pada hari rabu tanggal 14 Februari 2018, peneliti telah mengumpulkan data dari hasil tes observasi awal melakukan teknik passing atas bolavoli sebelum diberikan tindakan oleh peneliti. Diperoleh kesimpulan bahwa dari permainan bola besar, peserta didik sering melakukan kesalahan dalam melakukan teknik passing atas bolavoli. Saat melakukan teknik dasar passing atas ada tiga keterampilan dasar yang menjadi tolak ukur dalam penelitian ini yaitu: Sikap persiapan, sikap perkenaan, sikap akhir, dari ketiga keterampilan dasar tersebut telah diperoleh data passing atas bolavoli dengan jumlah peserta didik 35 terdapat 14 peserta didik (40\%) melakukan dengan benar yaitu $31 \%$ peserta didik melakukan sikap persiapan benar, 26\% peserta didik melakukan sikap perkenaan benar, 26\% peserta didik melakukan sikap akhir benar. Dapat diartikan lebih dari 60\% peserta didik kelas X Jasa Boga 3 SMK Negeri 1 Batu masih belum tuntas. Peserta didik dapat dinyatakan tuntas jika mampu melakukan 6 poin dari 9 poin pada indikator.

Peneliti memperoleh data hasil ketuntasan setiap indikator pada observasi awal dijelaskan pada tabel 1 sebagai berikut.

Tabel 1. Data Hasil Penilaian Observasi Awal Teknik Passing Atas Bolavoli $(\mathrm{N}=35)$

\begin{tabular}{|c|c|c|c|c|c|c|c|c|c|c|c|}
\hline & \multicolumn{11}{|c|}{ Teknik Passing Atas Bolavoli } \\
\hline & \multicolumn{3}{|c|}{ Sikap Persiapan } & \multicolumn{3}{|c|}{ Sikap Perkenaan } & \multicolumn{3}{|c|}{ Sikap Akhir } & \multirow{2}{*}{ Hasil } & \multirow{2}{*}{$\begin{array}{c}\text { Skor } \\
\text { Maksim } \\
\text { al }\end{array}$} \\
\hline & 1 & 2 & 3 & 1 & 2 & 3 & 1 & 2 & 3 & & \\
\hline $\begin{array}{l}\text { Jumlah } \\
\text { Benar }\end{array}$ & 27 & 18 & 18 & 16 & 19 & 15 & 13 & 19 & 17 & 162 & 315 \\
\hline $\begin{array}{l}\text { Jumlah } \\
\text { Maksimal }\end{array}$ & 35 & 35 & 35 & 35 & 35 & 35 & 35 & 35 & 35 & 315 & 315 \\
\hline $\begin{array}{l}\text { Persenta } \\
\text { se } \\
\text { Ketuntas } \\
\text { an }\end{array}$ & $77 \%$ & $51 \%$ & $51 \%$ & $46 \%$ & $54 \%$ & $43 \%$ & $37 \%$ & $54 \%$ & $49 \%$ & $51 \%$ & \\
\hline
\end{tabular}

Berdasarkan hasil observasi awal pada tabel 4.3 dapat disimpulkan bahwa persentase ketuntasan keseluruhan pada indikator teknik passing atas bolavoli sebesar $51 \%$. Persentase ketuntasan paling rendah $37 \%$ pada indikator sikap akhir, sikap setelah bola dipassing, gerakan lengan bergerak lurus sebagai gerakan lanjutan. Persentase ketuntasan paling tinggi $77 \%$ pada indikator sikap persiapan kedua kaki dibuka selebar bahu dengan salah satu kaki berada di depan.

\section{Paparan Data pada Siklus 1}

Setelah mengetahui tingkat kesulitan dalam dalam memahami materi pembelajaran yang dialami oleh peserta didik, peneliti berkoordinasi dan berkonsultasi dengan guru pendidikan jasmani untuk mencari alternatif pemecahan masalah dalam hal teknik passing atas. Salah satu alternatif yang dilakukan adalah dengan mengajarkan passing atas dikombinasikan dengan bolavoli gandu, supaya memudahkan peserta didik melakukan passing atas. Selanjutnya perlu disusun sebuah RPP untuk tiga kali pertemuan dengan menggunakan metode bermain.

Kemudian melaksanakan pembelajaran dengan materi teknik passing atas bolavoli pada permainan bola besar yang dilakukan pada hari Selasa 23, 30 Juli dan 6 Agustus, dimana pada siklus 1 berlangsung selama tiga kali pertemuan. Hasil tindakan pada siklus 1 dilihat dari aspek sikap persiapan yang dilakukan oleh 35 peserta didik. Pada saat sikap persiapan: (1) pada indikator kedua kaki dibuka selebar bahu dengan salah satu kaki berada didepan, didapatkan hasil persentase benar siswa dari observer 1 sebanyak $80 \%$ sedangkan dari observer 2 sebanyak $80 \%$, (2) sikap lutut ditekuk, badan agak condong sedikit kedepan dengan tangan siap berada di depan dada, didapatkan hasil persentase benar siswa dari observer 1 sebanyak 63\% sedangkan dari observer 2 sebanyak 66\%, (3) sikap jasri-jari tangan secara keseluruhan membentuk setengah bulatan dan jarak antara jari-jari yang satu dengan yang lainnya agak direnggangkan sedikit, didapatkan hasil persentase benar siswa dari observer sebanyak 54\% sedangkan dari observer 2 sebanyak $57 \%$. Dilihat dari aspek sikap perkenaan yang dilakukan oleh 35 peserta didik. Pada saat Sikap perkenaan: (1) pada indikator pada saat passing atas, bola bersentuhan dengan ujung jari pada ruas pertama dan kedua ibu jari, didapatkan 
hasil persentase benar siswa dari observer 1 sebanyak $54 \%$ sedangkan dari observer 2 sebanyak $54 \%$, (2) sikap ketika jari-jari bersentuhan dengan bola, maka jari-jari agak ditegangkan sedikit, didapatkan hasil persentase benar siswa dari observer 1 sebanyak 57\% sedangkan dari observer 2 sebanyak $57 \%$, (3) sikap gerakan lanjutan pergelangan tangan kearah depan atas dengan gerakan agak eksplosif, didapatkan hasil persentase siswa dari observer 1 sebanyak $40 \%$ sedangkan dari observer 2 sebanyak $43 \%$. Dilihat dari aspek sikap akhir yang dilakukan oleh 35 peserta didik. Pada saat Sikap akhir: (1) pada indikator setelah bola dipassing, gerakan lengan bergerak lurus sebagai gerakan lanjutan, didapatkan hasil persentase siswa dari observer 1 sebanyak 49\% sedangkan dari observer 2 sebanyak 49\%, (2) sikap diikuti badan dan langkah kaki kedepan agar koordinasi gerakan terjaga dengan baik, didapatkan hasil persentase siswa dari observer 1 sebanyak $63 \%$ sedangkan dari observer 2 sebanyak $63 \%$, (3) sikap pandangan pemain harus tetap mengikuti arah bola, didapatkan hasil persentase siswa dari observer 1 sebanyak $77 \%$ sedangkan dari observer 2 sebanyak $80 \%$.

Hasil dari siklus 1 dapat dilihat pada tabel 2 sebagai berikut:

Tabel 2. Data Hasil Analisis Penelitian Teknik Passing Atas Bolavoli pada Pertemuan Ketiga Siklus 1 (N=35)

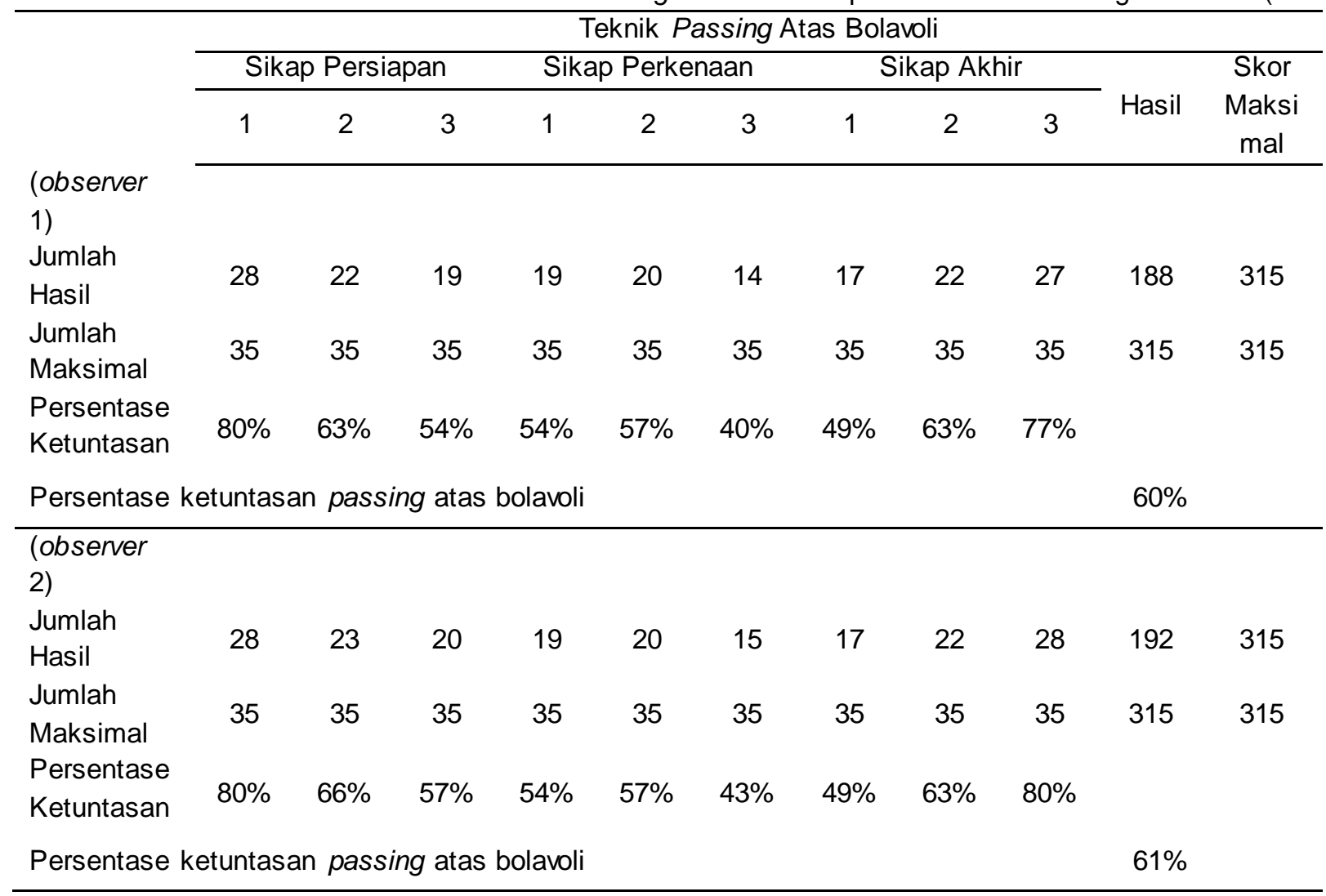

Berdasarkan hasil data mengenai tingkat keberhasilan peserta dalam melakukan teknik passing atas bolavoli pada permainan bola besar di kelas X Jasa Boga 3 SMK Negeri 1 Batu Kota Batu telah diperoleh hasil dari tindakan siklus 1 selama tiga kali pertemuan, pada passing atas bolavoli tingkat keberhasilan persentasenya mencapai kategori cukup. Maka dapat disimpulkan bahwa tujuan dari penelitian ini sudah tercapai, akan tetapi peneliti masih perlu mengoptimalkan dan meningkatkan lagi. Berdasarkan evaluasi dan refleksi pada siklus 1 yang dilakukan peneliti dengan guru pendidikan jasmani, maka perlu diadakan perbaikan untuk dapat meningkatkan teknik passing atas bolavoli pada permainan bola besar dengan metode bermain yang dilakukan pada siklus 2 .

\section{Paparan Data pada Siklus 2}

Berdasarkan hasil evaluasi dan refleksi pada siklus 1 yang dilakukan peneliti dengan guru pendidikan jasmani, maka perlu diadakan perbaikan untuk dapat meningkatkan teknik passing atas bolavoli pada permainan bola besar dengan metode bermain yang dilakukan pada siklus 2. Peneliti akan mempersiapkan RPP pada siklus 2 untuk tiga kali pertemuan. 
Kemudian melaksanakan pembelajaran dengan materi teknik passing atas bolavoli pada permainan bola besar yang dilakukan pada hari Selasa 13, 20, 27 Agustus 2019, dimana pada siklus 2 berlangsung selama tiga kali pertemuan. Hasil tindakan pada siklus 2 dilihat dari aspek sikap persiapan yang dilakukan oleh 35 peserta didik. Pada saat sikap persiapan: (1) pada indikator kedua kaki dibuka selebar bahu dengan salah satu kaki berada didepan, didapatkan hasil persentase benar siswa dari observer 1 sebanyak $97 \%$ sedangkan dari observer 2 sebanyak $97 \%$, (2) sikap lutut ditekuk, badan agak condong sedikit kedepan dengan tangan siap berada di depan dada, didapatkan hasil persentase benar siswa dari observer 1 sebanyak $91 \%$ sedangkan dari observer 2 sebanyak $91 \%$, (3) sikap jasri-jari tangan secara keseluruhan membentuk setengah bulatan dan jarak antara jari-jari yang satu dengan yang lainnya agak direnggangkan sedikit, didapatkan hasil persentase benar siswa dari observer sebanyak $83 \%$ sedangkan dari observer 2 sebanyak $86 \%$. Sikap Perkenaan: (1) pada indikator pada saat passing atas, bola bersentuhan dengan ujung jari pada ruas pertama dan kedua ibu jari, didapatkan hasil persentase benar siswa dari observer 1 sebanyak $77 \%$ sedangkan dari observer 2 sebanyak $80 \%$, (2) sikap ketika jari-jari bersentuhan dengan bola, maka jari-jari agak ditegangkan sedikit, didapatkan hasil persentase benar siswa dari observer 1 sebanyak $80 \%$ sedangkan dari observer 2 sebanyak $83 \%$, (3) sikap gerakan lanjutan pergelangan tangan kearah depan atas dengan gerakan agak eksplosif, didapatkan hasil persentase siswa dari observer 1 sebanyak $74 \%$ sedangkan dari observer 2 sebanyak $74 \%$. Sikap akhir: (1) pada indikator setelah bola dipassing, gerakan lengan bergerak lurus sebagai gerakan lanjutan, didapatkan hasil persentase siswa dari observer 1 sebanyak $66 \%$ sedangkan dari observer 2 sebanyak 69\%, (2) sikap diikuti badan dan langkah kaki kedepan agar koordinasi gerakan terjaga dengan baik, didapatkan hasil persentase siswa dari observer 1 sebanyak $86 \%$ sedangkan dari observer 2 sebanyak $86 \%$, (3) sikap pandangan pemain harus tetap mengikuti arah bola, didapatkan hasil persentase siswa dari observer 1 sebanyak 94\% sedangkan dari observer 2 sebanyak 94\%. Hasil dari siklus 2 dapat dilihat pada tabel sebagai berikut:

Tabel 3. Data Hasil Analisis Penelitian Teknik Passing Atas Bolavoli pada Pertemuan Ketiga Siklus 2 (N=35)

\begin{tabular}{|c|c|c|c|c|c|c|c|c|c|c|c|}
\hline & \multicolumn{11}{|c|}{ Teknik Passing Atas Bolavoli } \\
\hline & \multicolumn{3}{|c|}{ Sikap Persiapan } & \multicolumn{3}{|c|}{ Sikap Perkenaan } & \multicolumn{3}{|c|}{ Sikap Akhir } & \multirow[t]{2}{*}{ Hasil } & \multirow{2}{*}{$\begin{array}{c}\text { Skor } \\
\text { Maksimal }\end{array}$} \\
\hline & 1 & 2 & 3 & 1 & 2 & 3 & 1 & 2 & 3 & & \\
\hline \multicolumn{11}{|l|}{ (observer } & \\
\hline $\begin{array}{l}\text { Jumlah } \\
\text { Hasil }\end{array}$ & 34 & 32 & 29 & 27 & 28 & 26 & 23 & 30 & 33 & 262 & 315 \\
\hline $\begin{array}{l}\text { Jumlah } \\
\text { Maksimal }\end{array}$ & 35 & 35 & 35 & 35 & 35 & 35 & 35 & 35 & 35 & 315 & 315 \\
\hline $\begin{array}{l}\text { Persentase } \\
\text { Ketuntasan }\end{array}$ & $97 \%$ & $91 \%$ & $83 \%$ & $77 \%$ & $80 \%$ & $74 \%$ & $66 \%$ & $86 \%$ & $94 \%$ & & \\
\hline \multicolumn{9}{|c|}{ Persentase ketuntasan passing atas bolavoli } & \multicolumn{3}{|c|}{$83 \%$} \\
\hline \multicolumn{12}{|l|}{$\begin{array}{l}\text { (observer } \\
\text { 2) }\end{array}$} \\
\hline $\begin{array}{l}\text { Jumlah } \\
\text { Hasil }\end{array}$ & 34 & 32 & 30 & 38 & 28 & 29 & 26 & 30 & 33 & 266 & 315 \\
\hline $\begin{array}{l}\text { Jumlah } \\
\text { Maksimal }\end{array}$ & 35 & 35 & 35 & 35 & 35 & 35 & 35 & 35 & 35 & 315 & 315 \\
\hline $\begin{array}{l}\text { Persentase } \\
\text { Ketuntasan }\end{array}$ & $97 \%$ & $91 \%$ & $86 \%$ & $80 \%$ & $83 \%$ & $74 \%$ & $69 \%$ & $86 \%$ & $94 \%$ & & \\
\hline \multicolumn{9}{|c|}{ Persentase ketuntasan passing atas bolavoli } & \multicolumn{3}{|c|}{$84 \%$} \\
\hline
\end{tabular}

Melihat dari hasil data mengenai tingkat keberhasilan peserta didik kelas $X$ Jasa Boga 3 dalam melakukan teknik passing atas bolavoli pada permainan bola besar yang telah diperoleh dari tindakan siklus 2, maka dapat disimpulkan tujuan dari penelitian ini telah tercapai dan tidak perlu diadakan tindak lanjut pada siklus berikutnya. 


\section{PEMBAHASAN}

Peneliti melakukan observasi awal pada pembelajaran dengan materi teknik passing atas bolavoli pada permainan bola besar di SMK Negeri 1 Batu dan hasil observasi awal yang dilaksanakan oleh peneliti dalam proses kegiatan pembelajaran dengan materi teknik passing atas bolavoli memperoleh hasil belajar peserta didik yang masih banyak melakukan kesalahan pada praktik teknik passing atas bolavoli, sehingga persentase hasil belajar peserta didik berada pada taraf kurang. Berdadarkan hasil belajar peserta didik y ang masih dalam taraf persentase yang kurang, maka peneliti dan guru melakukan diskusi tentang perencanaan pelaksanaan tindakan menggunkan metode bermain yang bertujuan untuk meningkatkan hasil belajar teknik passing atas bolavoli.

Pentingnya observasi dalam kegiatan evaluasi pembelajaran mengharuskan guru untuk lebih teliti. Menurut pendapat beberapa ahli menyatakan bahwa karakteristik anak usia SMA dibagi menjadi 3, yaitu secara fisikal, secara kognitif, dan secara afektif (Rogers, 2021; S. Sihaloho et al., 2019; Sarmiento \& Orale, 2016; Soegoto et al., 2018). Observasi adalah suatu proses pengamatan dan pencatatan secara sistematis, logis, objektif, dan rasional mengenai berbagai fenomena, baik dalam situasi yang sebenarnya maupun dalam situasi buatan untuk mencapai tujuan tertentu (de Vries, 2018; van Gestel, 2018; Van Hoecke, 2016; Webley, 2016). Metode bermain cukup populer digunakan oleh para guru untuk membangun suasana kelas yang menyenangkan. Melalui permainan, metode yang baik digunakan dalam pembelajaran akan menciptakan anak dapat belajar dengan baik dan sungguh-sungguh Zaman \& Helmi (2009:4). Metode bermain adalah cara yang digunakan guru dalam menyampaikan ilmu yang tepat melalui hubungan dengan anak pada saat berlangsung pembelajaran sehingga menghasilkan pemahaman yang maksimal dengan mencapai kompetensi yang mditetapkan melalui aktifitas yang dipilih sendiri oleh anak atas dasar kesenangan bukan karna hadiah atau pujian tanpa pertimbangan akhir (Andrews, 2017; Eichberg, 2015; Gil-Gimeno et al., 2018; Pill, 2014).

Peneliti mengamati dan mencatat keterampilan passing atas dari beberapa indikator yang meliputi: (1) sikap persiapan, (2) sikap perkenaan, (3) sikap akhir. Dari hasil pengamatan, peneliti menyimpulkan bahwa untuk pembelajaran permainan bola besar yang paling rendah adalah passing atas. Peneliti melakukan tes keterampilan passing atas melalui game sederhana dengan cara passing atas secara berpasang-pasangan, peneliti mengamati dan mencatat keterampilan passing atas dalam pembelajaran permainan bola besar dengan melakukan tes selama 30 detik.

Berdasarkan hasil tes keterampilan awal diperoleh hasil tes keterampilan passing atas bolavoli ditemukan bahwa $69 \%$ siswa salah dalam melakukan sikap persiapan, $74 \%$ siswa salah dalam melakukan sikap perkenaan, dan $74 \%$ siswa salah dalam melakukan sikap akhir pada teknik passing atas bolavoli.

Untuk itu peneliti melakukan tindakan guna untuk meningkatkan keterampilan passing atas bolavoli pada permainan bola besar menggunakan metode bermain. Pada saat melakukan penelitian, pelaksanaan pembelajaran siklus 1 dilakukan tiga kali pertemuan di setiap hari Selasa pukul 13.00 WIB sampai dengan 14.30 WIB.. Berdasarkan paparan data penelitian siklus 1 melalui penerapan metode bermain dalam pembelajaran PJOK dengan materi teknik passing atas bolavoli dalam permainan bola besar pada kelas $X$ Jasa Boga 3 SMK Negeri 1 Batu. Metode bermain dipilih yaitu permainan lari zig-zag dan lempar tangkap, permainan jongkok dan berdiri, permainan bola bergilir untuk diterapkan pada pembelajaran PJOK karena dengan adanya penerapan metode bermain peserta didik dapat melakukan pembelajaran lebih rileks dan juga tanpa unsur keterpaksaan yang membuat peserta didik menjadi semangat ketika proses pembelajaran dengan permainan sehingga peserta didik menjadi senang ketika melakukan pembelajaran PJOK.

Kesimpulan yang diperoleh dari siklus 1 yaitu hasil belajar yang didapatkan masih kurang maksimal, hal ini disebabkan oleh fokus mayoritas peserta didik terhadap pembelajaran masih kurang, Terdapat peserta didik yang belum melakukan teknik passing atas bolavoli dengan baik dan benar, dikarenakan terdapat peserta didik yang bergurau, mengobrol, dan tidak memperhatikan ketika guru sedang memberikan materi. Oleh karena itu penelitian dilanjutkan ke siklus berikutnya atau siklus 2 untuk mendorong peserta didik memperoleh hasil maksimal dan memperbaiki kelemahan yang muncul pada siklus 1.

Pelaksanaan siklus 2 dilakukan tiga kali pertemuan di setiap hari Selasa pukul 13.00 WIB sampai dengan 14.30 WIB.. Berdasarkan paparan data penelitian siklus 1 melalui penerapan metode bermain dalam pembelajaran PJOK dengan materi teknik passing atas bolavoli dalam permainan bola besar pada kelas $X$ Jasa Boga 3 Negeri 1 Batu. Jenis permainan yang dipilih untuk digunakan pada pembelajaran PJOK yaitu permainan berjalan dan sasaran, permainan feed and move (mengumpan dan berpindah), dan permainan 
throw and catch (lempar dan tangkap). Jenis permainan tersebut merupakan hasil dari diskusi dan kajian peneliti dengan guru berdasarkan evaluasi dan refleksi siklus 1.

Kesimpulan yang diperoleh dari siklus 2 yaitu dalam suasana pembelajaran seluruh peserta didik mengikuti proses pembelajaran dengan baik meskipun masih ada enam peserta didik yang masih belum tuntas dalam melaksanakan teknik passing atas bolavoli, dengan catatan cukup dalam ketuntasan melaksanakan teknik passing atas bolavoli, dikarenakan peserta didik tersebut memiliki kemampuan untuk menyerap materi belajar yang masih rendah dibandingkan dengan teman sebayanya selain itu ada beberapa peserta didik yang belum melakukan pembelajaran secara maksimal dikarenakan tidak mengikuti seluruh proses pembelajaran.

Berdasarkan paparan data di atas dapat dinyatakan bahwa terdapat peningkatan hasil belajar peserta didik pada tahap prasiklus (observasi awal), ke tahap siklus 1 dan siklus 2. Nilai hasil belajar peserta didik pada siklus 1 dan siklus 2 sudah mencapai persentase ketuntasan belajar yang sudah ditargetkan. Dengan demikian dapat dibuktikan dengan adanya penerapan metode bermain pada pembelajaran PJOK dapat meningkatkan hasil belajar peserta didik pada materi teknik passing atas bolavoli dalam permainan bola besar.

\section{KESIMPULAN}

Dari hasil data yang diperoleh pada semua tindakan yang telah dilakukan pada siklus 1 dan 2, maka dapat disimpulkan bahwa metode bermain dapat meningkatkan keterampilan passing atas bolavoli pada permainan bola besar di kelas $X$ Jasa Boga 3 SMK Negeri 1 Batu.

\section{DAFTAR PUSTAKA}

Ajeesh, P. T., \& Pradeep, C. S. (2013). Personality characteristics of men and women volleyball players. International Journal of Social Science and Interdisciplinary Research, 2(5), 79-85.

Allard, F., \& Starkes, J. L. (2016). Perception in Sport: Volleyball. Journal of Sport Psychology, 2(1), 22-33. https://doi.org/10.1123/jsp.2.1.22

Anastasiia, M., \& Physical, C. (2017). Forming Physical Culture Teachers' Motivation To Study. Science and Education, 23(8), 150-156. https://doi.org/10.24195/2414-4665-2017-8-22

Andrews, G. J. (2017). From post-game to play-by-play. Progress in Human Geography, 41(6), 766-794. https://doi.org/10.1177/0309132516660207

Ariffiansyah, G. (2019). Peningkatan Kemampuan Kelincahan Gerak Akibat Latihan Kelincahan T-Drill Maju dan T-Drill Mundur Terhadap Kelincahan Gerak Olahragawan Karate Dojo Cakrawala Kota Malang. Sport Science and Health, 1(3), 227-232. http://journal2.um.ac.id/index.php/jik/index

Beardt, B. S., McCollum, M. R., Hinshaw, T. J., Layer, J. S., Wilson, M. A., Zhu, Q., \& Dai, B. (2018). Lowerextremity kinematics differed between a controlled drop-jump and volleyball-takeoffs. Journal of Applied Biomechanics, 34(4), 327-335. https://doi.org/10.1123/jab.2017-0286

Bryman \& Bell. (2015). Business Research Methods. Business Research Method, 777.

Curry-Sumner, I., \& van der Schaaf, M. (2018). The Theory and Practice of Teaching and Guiding Legal Research Skills. Law and Method, 1(1), 64-84. https://doi.org/10.5553/rem/221225082011001001005

de Vries, U. (2018). Kuhn and Legal Research. Law and Method, 3(1), 7-25. https://doi.org/10.5553/rem/221225082013003001002

Department for Education. (2013). Physical education programmes of study: key stages 3 and 4 National curriculum in England Purpose of study. London: DfE, 1-3. https://www.gov.uk/government/uploads/system/uploads/attachment_data/file/239086/SECONDARY_ national_curriculum___Physical_education.pdf

Eichberg, H. (2015). Play as production - production as game? East Asian Sport Thoughts, 4, 25-44.

Gil-Gimeno, J., Sánchez-Capdequí, C., \& Beriain, J. (2018). Play, game, and videogame: The metamorphosis of play. Religions, 9(5). https://doi.org/10.3390/rel9050162 
Hendarto, M. H., Januarto, O. B., \& Tomi, A. (2020). Meningkatkan Backhand Overhead Clear Bulutangkis Dengan Metode Drill. Sport Science and Health, 2(4), 232-238. http://journal2.um.ac.id/index.php/jik/article/view/11685/5575

Kumar, M., Talib, S. A., \& Ramayah, T. (2013). Research Design and Proposal Writing. Business Research Method, 1(Spring), 56-56.

Marques Junior, N. K. (2018). Specific periodization for the volleyball: a training organizationoverview. MOJ Sports Medicine, 2(3). https://doi.org/10.15406/mojsm.2018.02.00056

Mergheş, P. E., Grădinaru, S., \& Grădinaru, S. (2014). Study on the somatic profile of the volleyball outside hitter. Timisoara Physical Education \& Rehabilitation Journal, 7(13), 21-26. http://search.ebscohost.com/login. aspx?direct=true\&db=s3h\&AN=100329137\&lang=pt -br\&site=ehostlive

Oh, J., \& Graber, K. C. (2019). Physical Education Teacher Education Leaders' Perceptions on a National Curriculum in Physical Education. Research Quarterly for Exercise and Sport, 90(3), 362-376. https://doi.org/10.1080/02701367.2019.1603988

Palao, J. M., \& sup 2, D. (2014). Normative profiles for serve speed for the training of the serve and reception

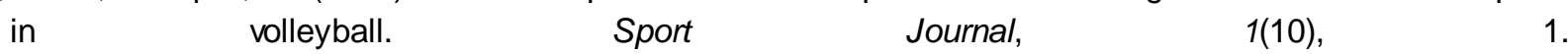
http://ezproxy.library.ubc.ca/login?url=http://search.ebscohost.com/login. aspx?direct=true\&db=sph\&A $\mathrm{N}=101867279 \&$ login. asp\&site $=$ ehost-live\&scope $=$ site

Physical, T., \& Tools, L. (2014). Physical Literacy Assessment in Canada. Physical \& Health Education Journal, 80(1), 38-40.

Pill, S. (2014). Game Play: What Does It Mean for Pedagogy to Think Like a Game Developer? Journal of Physical Education, Recreation \& Dance, 85(1), 9-15. https://doi.org/10.1080/07303084.2013.838119

Reeser, J. C., Fleisig, G. S., Cools, A. M. J., Yount, D., \& Magnes, S. A. (2013). Biomechanical insights into the aetiology of infraspinatus syndrome. British Journal of Sports Medicine, 47(4), 239-244. https://doi.org/10.1136/bjsports-2011-090918

Rogers, M. (2021). Possible Articulation for the Junior High School with the Elementary School and the Senior High School. The Mathematics Teacher, 38(6), 252-258. https://doi.org/10.5951/mt.38.6.0252

S. Sihaloho, F. A., Martono, T., \& Daerobi, A. (2019). The Implementation of School Literacy Movement at the Senior High School. International Journal of Educational Research Review, 4(1), 88-96. https://doi.org/10.24331/ijere.486907

Sarmiento, D. H., \& Orale, R. L. (2016). Senior High School Curriculum in the. Of Academic Research, 3, 1223.

Schulz, J. (2017). Visual research methods in educational research. International Journal of Research \& Method in Education, 40(3), 327-328. https://doi.org/10.1080/1743727x.2017.1308657

Soegoto, E. S., Yunus, I. P., \& Valentina, T. (2018). Smart School for Senior High School. IOP Conference Series: Materials Science and Engineering, 407(1). https://doi.org/10.1088/1757-899X/407/1/012003

Sprake, A., \& Temple, C. (2016). Physical Education or Physical Entertainment: where's the education in PE? Journal of Qualitative Research in Sport Studies, 10(1), 157-176. https://www.researchgate.net/profile/Andrew_Sprake/publication/327645699_Physical_Education_or_ Physical_Entertainment_where's_the_education_in_PE/links/5b9b790392851ca9ed06af95/PhysicalEducation-or-Physical-Entertainment-wheres-the-education-in-PE.pdfhtt

Tenpaku, M., Honda, T., Health, M., \& Education, P. (2018). Circulating extracellular vesicles are associated with lipid and insulin metabolism 3. Am J Physiol Endocrinol Metab.

Tilp, M., \& Rindler, M. (2013). Landing techniques in beach volleyball. Journal of Sports Science and Medicine, 12(3), 447-453.

Usher, W., Keegan, R., \& Edwards, A. (2016). Taking the "physical" out of physical education. Cogent Education, 3(1). https://doi.org/10.1080/2331186X.2016.1181025 
Utami, A. I. S., \& Winarno, M. E. (2020). Upaya Meningkatkan Hasil Belajar Tolak Peluru Gaya Ortodoks Melalui Metode Bermain di SMP Negeri 1 Durenan. Sport Science and Health, 2(2), 99-104. http://journal2.um.ac.id/index.php/jik/article/view/11217/5283

van Gestel, R. (2018). Research Methodologies in EU and International Law. Law and Method, 2(1), 72-77. https://doi.org/10.5553/rem/221225082012002001006

Van Hoecke, M. (2016). Methodology of Comparative Legal Research. Law and Method. https://doi.org/10.5553/rem/.000010

Wahyudi, A. (Universitas N. M., Wahyudi, U. (Universitas N. M., \& Amiq, F. (Universitas N. M. (2020). Peningkatan Keterampilan Teknik Dasar Passing Futsal Menggunakan Metode Drill dan Metode Bermain pada Ekstrakurikuler Futsal Madrasah Aliyah. Sport Science and Health, 2(1), 24-31. http://journal2.um.ac.id/index.php/jik/article/view/11103/5115

Webley, L. (2016). Stumbling Blocks in Empirical Legal Research: Case Study Research. Law and Method. https://doi.org/10.5553/rem/.000020

Willis, M. S., Education, P., \& Box, C. (2013). Heart Rate Variability (HRV) as a Tool for Diagnostic and Monitoring Performance in Sport and Physical Activities. Journal of Exercise Physiology Online, 16(3), 103-131.

Zaman, S., \& Helmi, D. R. (2009). 12 Permainan untuk Meningkatkan Intelegensi Anak. Visismedia.

Zhang, Y. (2016). Analysis of influential factors of Asian volleyball pass technique. Journal of Computational and Theoretical Nanoscience, 13(12), 10130-10133. https://doi.org/10.1166/jctn.2016.6226 